\title{
Effect of Some Plating Variables on Zinc Coated Low Carbon Steel Substrates
}

\author{
Bamidele M. Durodola ${ }^{1}$, Joseph A.O. Olugbuyiro \\ ${ }^{1}$ Department of Chemistry, College of Science and Technology; \\ Covenant University, Ota, Ogun state, Nigeria \\ *Corresponding Author: olugbuyiro@yahoo.com
}

\begin{abstract}
This work examined the effect of plating variables on zinc coated low carbon steel substrates. The electrodeposition of steel substrates was carried out in zinc electrolyte bath. Time, voltage, distance from the anode to the cathode and the immersion depth served as plating variables. The results showed that weight gained increases as the plating time increases for the constant depth of immersion while the weight gained per unit time by varying immersion depth is irregular. Also, the study demonstrated that sample plated for 20 minutes; $20 \mathrm{~cm}$ from the anode, $45 \mathrm{~cm}$ depth of immersion at $0.8 \mathrm{~V}$ exhibited the best plating properties with homogeneity of diffuse plating efficiency.
\end{abstract}

Keywords: Variables, Zinc-coated low carbon steel substrates, Depth of immersion, Electrodeposition

\section{INTRODUCTION}

The use of materials has encountered increase number of stresses brought about by recent technology. Both the use and the stresses have probably grown at a greater rate than the number of materials that can be used to meet them. This is particularly true for structural materials which are almost entirely metallic ${ }^{1}$. Combination of stresses such as wear (caused by friction), corrosion (due to chemical) and high temperature have imposed restriction on the use of metallic materials.

However, in view of these negative effects, many new alloys have been produced with improved properties to subdue the negative effects posed by different environment ${ }^{2}$. But little is the protection that can be afforded by this means alone. Chemical attack occurs mostly in marine environment such as when ambient oxygen, droplets of sea salt and impurities in the fuel combine to form molten sodium which attack the metallic turbine blades, ship bodies and submarines $^{3}$. Thus, there is increasing fear that someday coating of metals will be subdued by these interacting stresses if nothing is done to forestall such occurrences. Therefore, the present 
work has examined the effect of plating variables on zinc-coating low carbon steels, in particular, to understudy more effective conditions for electrodeposition.

\section{MATERIALS AND METHODS}

\subsection{Materials}

The low carbon steel rod substrate used for this research was obtained from Osogbo Steel Rolling in Osun State, Nigeria. The chemical composition of the steel was analysed with mass spectrometer and analysis is shown in Table 1 . The steel was later cut into cylindrical pieces with dimension of $20 \mathrm{~mm}$ diameter by $40 \mathrm{~mm}$ length.

Table 1. Chemical Composition of Low Carbon Steel

$\begin{array}{llllllllllllllll}\text { Elements } & \mathrm{C} & \mathrm{S} & \mathrm{Si} & \mathrm{P} & \mathrm{Mn} & \mathrm{Ni} & \mathrm{Cu} & \mathrm{Mo} & \mathrm{V} & \mathrm{Ti} & \mathrm{Al} & \mathrm{Mg} & \mathrm{Sn} & \mathrm{Fe} \\ \text { wt\% } & 0.18 & 0.08 & 0.10 & 0.62 & 0.75 & 0.010 & 0.23 & 0.082 & 0.005 & 0.002 & 0.006 & 0.004 & 0.008 & 97.60\end{array}$

\subsection{Samples Pre-Treatment before Electroplating Operations}

The samples were removed from the desiccators in turn and pickled in $0.5 \mathrm{M} \mathrm{H}_{2} \mathrm{SO}_{4}$ for 2 minutes, then rinsed in distilled water before degreasing in an 100 litre electrolytic degreasing tank containing alkaline solution and rinsed in distilled water for 2 minutes. The samples were weighed using a digital weighing balance model Mettler Toledo Pb153 of accuracy $\pm 0.001 \mathrm{~g}$ and the weight was recorded as the initial weight.

\subsection{Electroplating Operation}

The samples were electroplated at 0.8 volt for different plating times ranging from 10mins $30 \mathrm{mins}$, and the distance from anode to cathode varied from $10 \mathrm{~cm}-30 \mathrm{~cm}$ at varying immersion depth from $35 \mathrm{~cm}-55 \mathrm{~cm}$. The surfaces of the samples were activated with acid solution. The samples were then dipped into the zinc plating bath and the electroplating rectifier switched on. The electroplated samples were removed, passivated, dried and the weights recorded.

\section{RESULTS}

Table 2: Weight Deposited (g) of Zinc on low carbon steel at varying depth of immersion and at $10 \mathrm{~cm}$ distance from anode

$\begin{array}{ccccc}\begin{array}{c}\text { Weight } \\ \text { Gained(g) }\end{array} & \begin{array}{c}\text { Weight deposited per } \\ \text { unit area }\left(\mathrm{mg} / \mathrm{mm}^{2}\right)\end{array} & \begin{array}{c}\text { Thickness } \\ (\mu \mathrm{m})\end{array} & \begin{array}{c}\text { Time } \\ (\text { Mins })\end{array} & \begin{array}{c}\text { Immersion } \\ \text { Depth(cm) }\end{array} \\ 0.02 & 1.82 & 0.052 & 10 & 35 \\ 0.10 & 9.12 & 0.260 & 15 & 40 \\ 0.04 & 3.65 & 0.104 & 20 & 45 \\ 0.08 & 7.29 & 0.208 & 25 & 50 \\ 0.06 & 5.47 & 0.156 & 30 & 55 \\ \text { Voltage }=0.8 \mathrm{~V} & & & & \end{array}$


Table 3: Weight Deposited (g) of Zinc on low carbon steel at constant depth of immersion and at $10 \mathrm{~cm}$ distance from anode

\begin{tabular}{|l|l|l|l|l|}
\hline $\begin{array}{l}\text { Weight Gained } \\
(\mathrm{g})\end{array}$ & $\begin{array}{l}\text { Weight deposited } \\
\text { per unit area } \\
\left(\mathrm{mg} / \mathrm{mm}^{2}\right)\end{array}$ & $\begin{array}{l}\text { Thickness } \\
(\mu \mathrm{m})\end{array}$ & $\begin{array}{l}\text { Time } \\
(\text { Mins })\end{array}$ & $\begin{array}{l}\text { Immersion } \\
\text { Depth } \\
(\mathrm{cm})\end{array}$ \\
\hline 0.06 & 5.47 & 0.156 & 10 & 35 \\
\hline 0.09 & 8.20 & 0.234 & 15 & 35 \\
\hline 0.14 & 12.76 & 0.364 & 20 & 35 \\
\hline 0.18 & 16.41 & 0.468 & 25 & 35 \\
\hline 0.20 & 18.23 & 0.520 & 30 & 35 \\
\hline
\end{tabular}

Voltage $=0.8 \mathrm{~V}$

Table 4: Weight Deposited (g) of Zinc on low carbon steel at varying depth of immersion and at $20 \mathrm{~cm}$ distance from anode

\begin{tabular}{|l|l|l|l|l|}
\hline $\begin{array}{l}\text { Weight Gained } \\
(\mathrm{g})\end{array}$ & $\begin{array}{l}\text { Weight deposited } \\
\text { per unit area } \\
\left(\mathrm{mg} / \mathrm{mm}^{2}\right)\end{array}$ & $\begin{array}{l}\text { Thickness } \\
(\mu \mathrm{m})\end{array}$ & $\begin{array}{l}\text { Time } \\
(\text { Mins })\end{array}$ & $\begin{array}{l}\text { Immersion } \\
\text { Depth } \\
(\mathrm{cm})\end{array}$ \\
\hline 0.06 & 5.47 & 0.156 & 10 & 35 \\
\hline 0.08 & 7.29 & 0.208 & 15 & 40 \\
\hline 0.12 & 10.94 & 0.312 & 20 & 45 \\
\hline 0.21 & 19.14 & 0.534 & 25 & 50 \\
\hline 0.12 & 10.94 & 0.312 & 30 & 55 \\
\hline
\end{tabular}

Voltage $=0.8 \mathrm{~V}$

Table 5: Weight Deposited (g) of Zinc on low carbon steel at constant depth of immersion and at $20 \mathrm{~cm}$ distance from anode

\begin{tabular}{|c|c|c|c|c|}
\hline $\begin{array}{l}\text { Weight Gained } \\
\text { (g) }\end{array}$ & $\begin{array}{l}\text { Weight deposited } \\
\text { per unit area } \\
\left(\mathrm{mg} / \mathrm{mm}^{2}\right)\end{array}$ & $\begin{array}{l}\text { Thickness } \\
(\mu \mathrm{m})\end{array}$ & $\begin{array}{l}\text { Time } \\
(\text { Mins })\end{array}$ & $\begin{array}{l}\text { Immersion } \\
\text { Depth } \\
(\mathrm{cm})\end{array}$ \\
\hline 0.04 & 3.65 & 0.10 & 10 & 45 \\
\hline 0.07 & 6.38 & 0.18 & 15 & 45 \\
\hline 0.12 & 10.94 & 0.31 & 20 & 45 \\
\hline 0.15 & 13.67 & 0.39 & 25 & 45 \\
\hline 0.18 & 16.41 & 0.47 & 30 & 45 \\
\hline
\end{tabular}

Voltage $=0.8 \mathrm{~V}$ 
Table 6: Weight Deposited (g) of Zinc on low carbon steel at varying depth of immersion and at $30 \mathrm{~cm}$ distance from anode

\begin{tabular}{|l|l|l|l|l|}
\hline $\begin{array}{l}\text { Weight Gained } \\
(\mathrm{g})\end{array}$ & $\begin{array}{l}\text { Weight deposited per } \\
\text { unit area }\left(\mathrm{mg} / \mathrm{mm}^{2}\right)\end{array}$ & $\begin{array}{l}\text { Thickness } \\
(\mu \mathrm{m})\end{array}$ & $\begin{array}{l}\text { Time } \\
(\text { Mins })\end{array}$ & $\begin{array}{l}\text { Immersion } \\
\text { Depth } \\
(\mathrm{cm})\end{array}$ \\
\hline 0.18 & 16.41 & 0.47 & 10 & 35 \\
\hline 0.04 & 3.65 & 0.10 & 15 & 40 \\
\hline 0.08 & 7.29 & 0.208 & 20 & 45 \\
\hline 0.10 & 9.12 & 0.260 & 25 & 50 \\
\hline 0.18 & 14.59 & 0.416 & 30 & 55 \\
\hline
\end{tabular}

Voltage $=0.8 \mathrm{~V}$

Table 7: Weight Deposited (g) of Zinc on low carbon steel at constant depth of immersion and at $30 \mathrm{~cm}$ distance from anode

\begin{tabular}{|c|c|c|c|c|}
\hline $\begin{array}{l}\text { Weight Gained } \\
\text { (g) }\end{array}$ & $\begin{array}{l}\text { Weight deposited } \\
\text { per unit area } \\
\left(\mathrm{mg} / \mathrm{mm}^{2}\right)\end{array}$ & $\begin{array}{l}\text { Thickness } \\
(\mu \mathrm{m})\end{array}$ & $\begin{array}{l}\text { Time } \\
\text { (Mins) }\end{array}$ & $\begin{array}{l}\text { Immersion } \\
\text { Depth } \\
\quad(\mathrm{cm})\end{array}$ \\
\hline 0.02 & 1.82 & 0.052 & 10 & 55 \\
\hline 0.05 & 4.56 & 0.130 & 15 & 55 \\
\hline 0.08 & 7.29 & 0.208 & 20 & 55 \\
\hline 0.10 & 9.12 & 0.260 & 25 & 55 \\
\hline 0.18 & 14.59 & 0.416 & 30 & 55 \\
\hline
\end{tabular}

Voltage $=0.8 \mathrm{~V}$

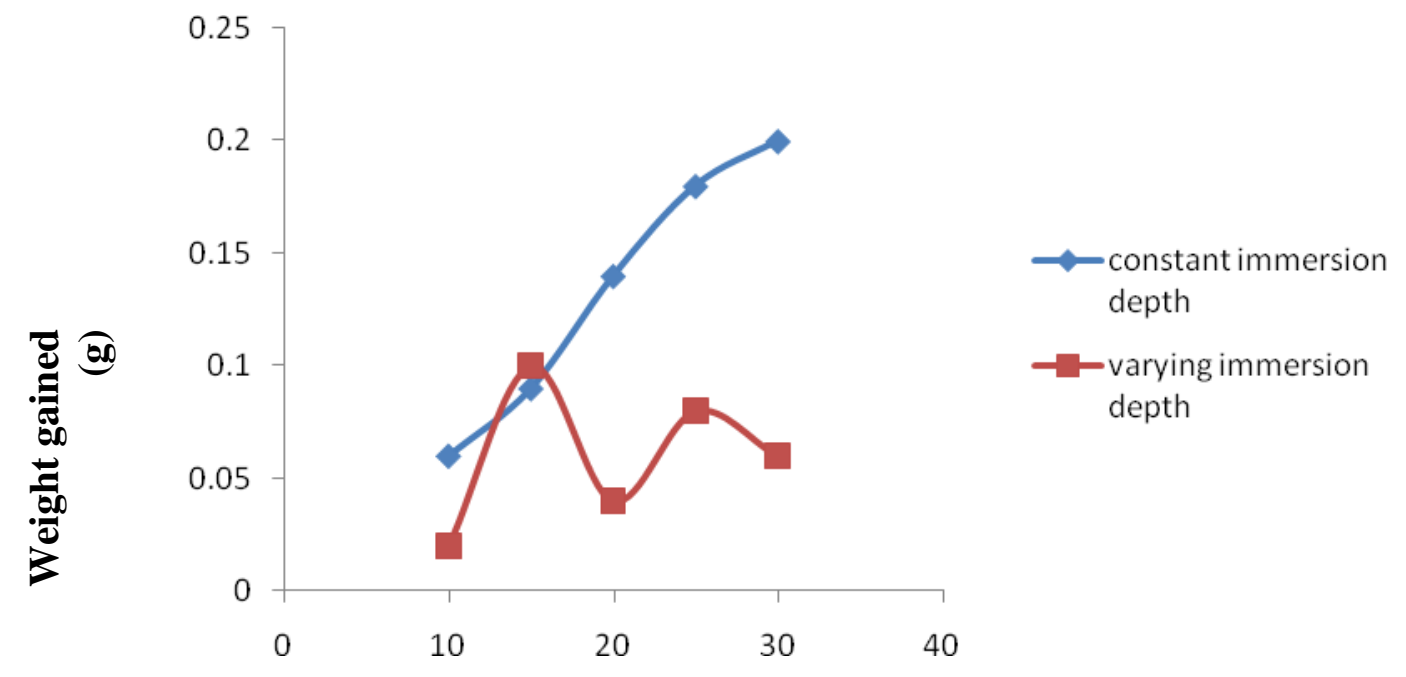

Time (Mins)

Fig. 1 Plot of Weight gained (g) against Time (Mins) of zinc plated on low carbon steel at $10 \mathrm{~cm}$ from the anode and at varying and constant immersion depth 

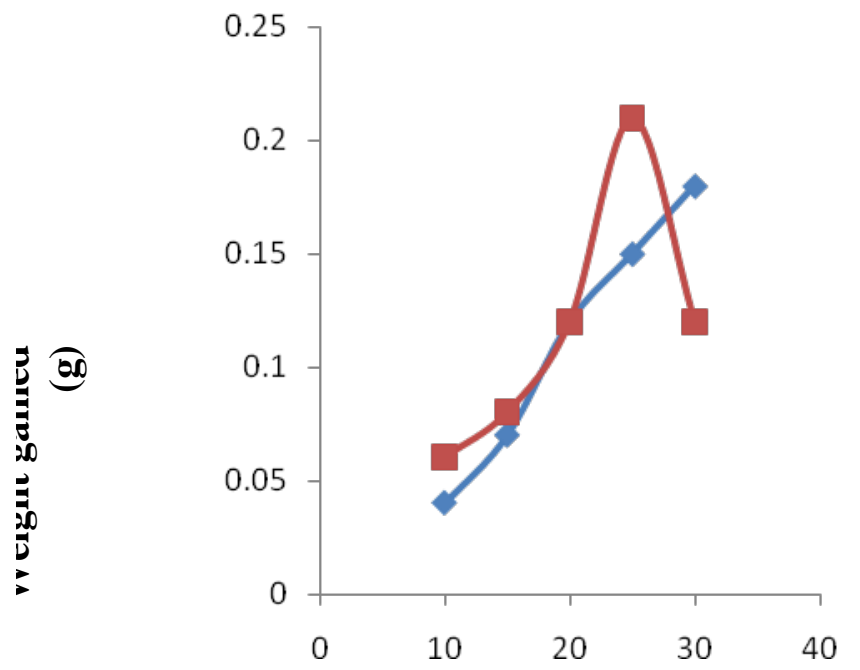

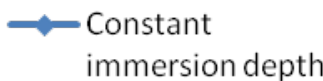

- Varying

immersion depth

Time (Mins)

Fig. 2 Plot of Weight gained (g) against Time (Mins) of zinc plated on low carbon steel at $20 \mathrm{~cm}$ from the anode and at varying and constant immersion depth

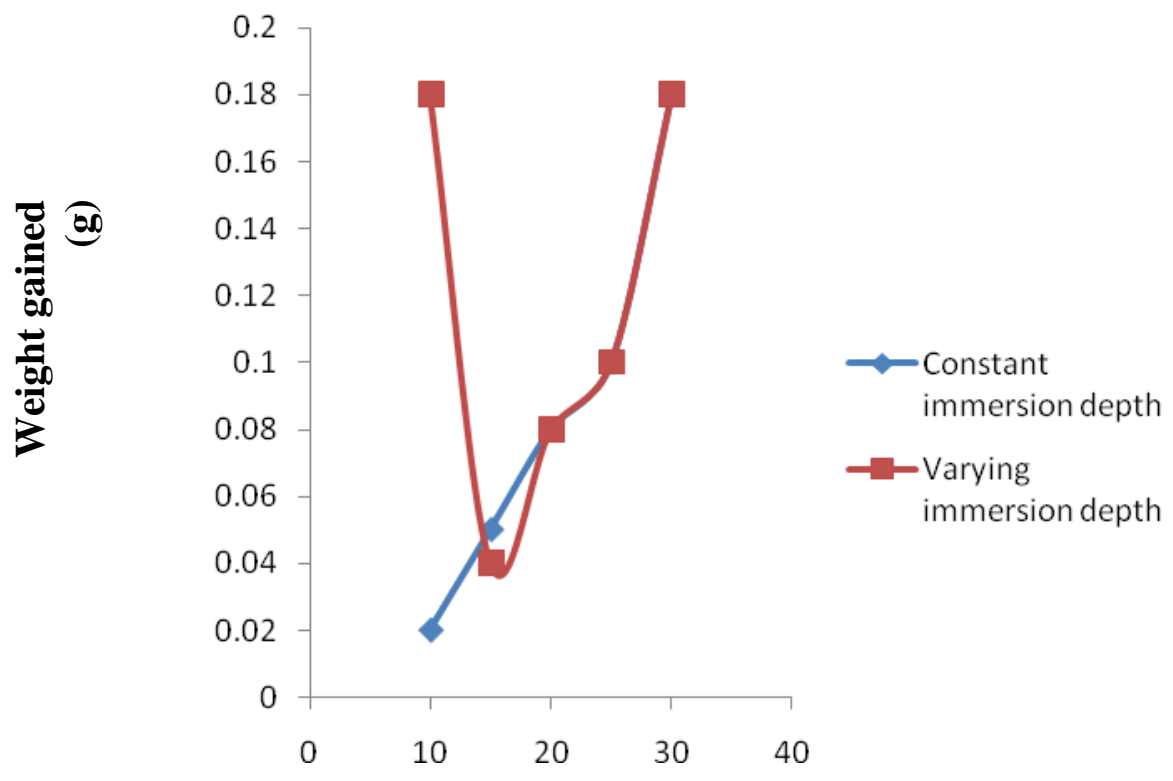

Time (Mins)

Fig. 3 Plot of Weight gained (g) against Time (Mins) of zinc plated on low carbon steel at $30 \mathrm{~cm}$ from the anode and at varying and constant immersion depth 


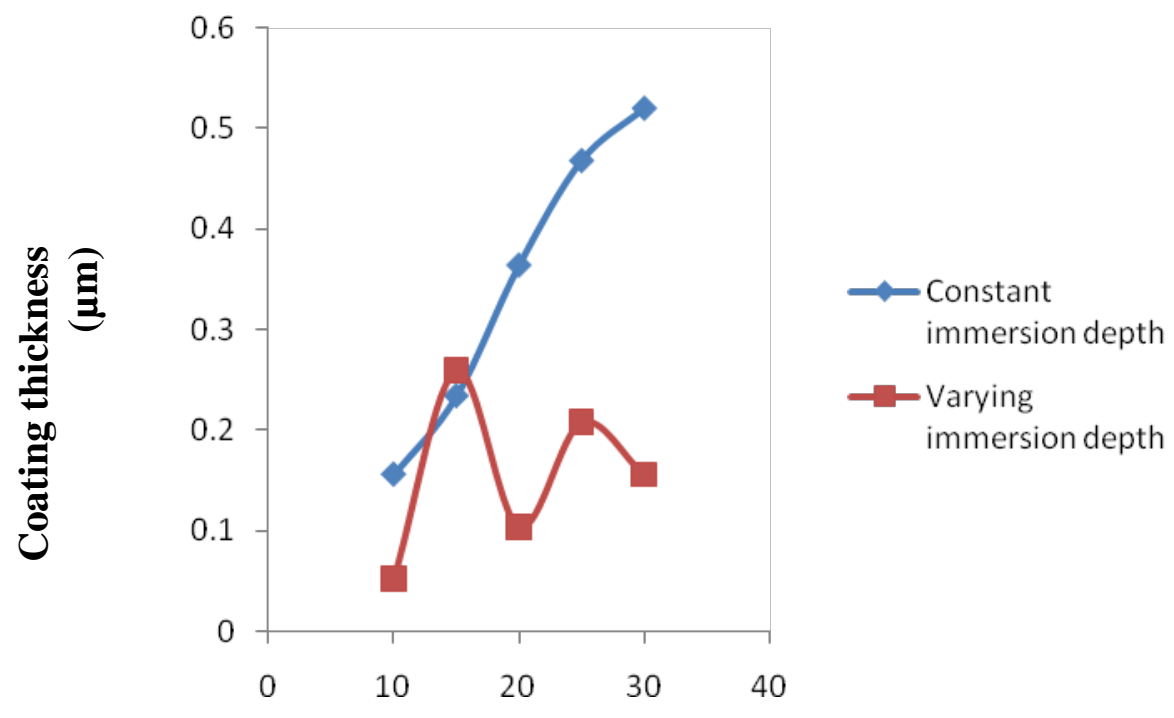

Time (Mins)

Fig. 4 Plot of Thickness ( $\mu \mathrm{m})$ against Time (Mins) of zinc plated on low carbon steel at $10 \mathrm{~cm}$ from the anode and at varying and constant immersion depth

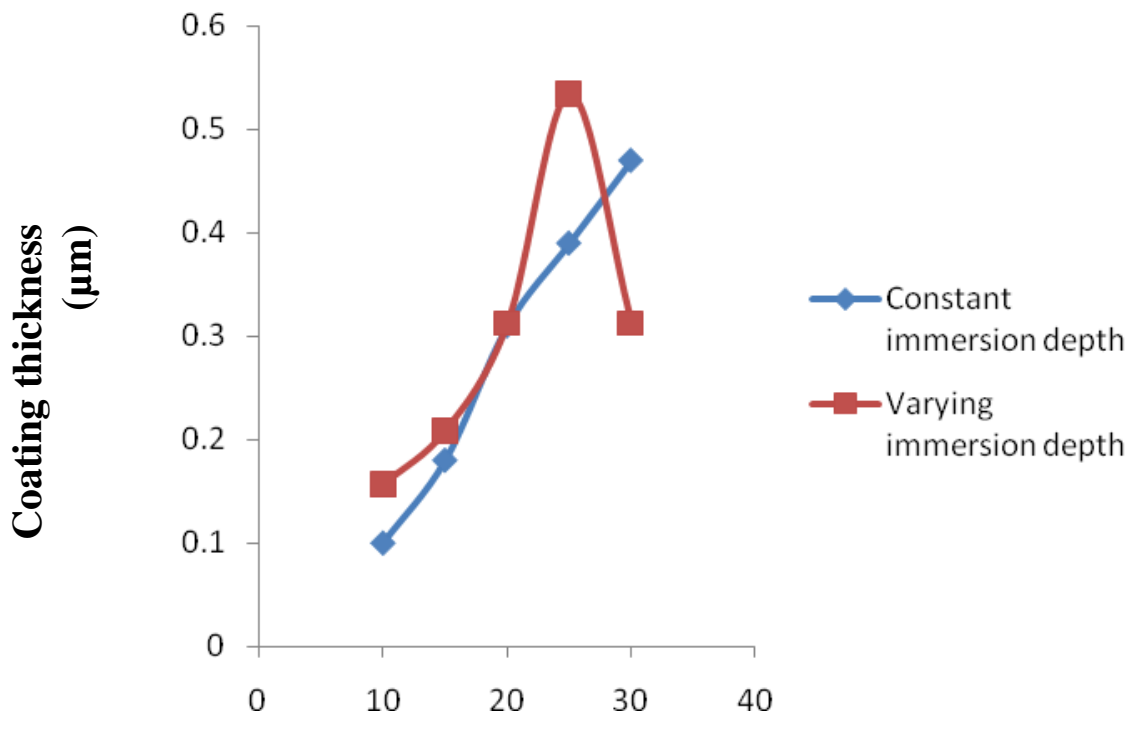

\section{Time (Mins)}

Fig. 5 Plot of Thickness ( $\mu \mathrm{m})$ against Time (Mins) of zinc plated on low carbon steel at $20 \mathrm{~cm}$ from the anode and at varying and constant immersion depth 


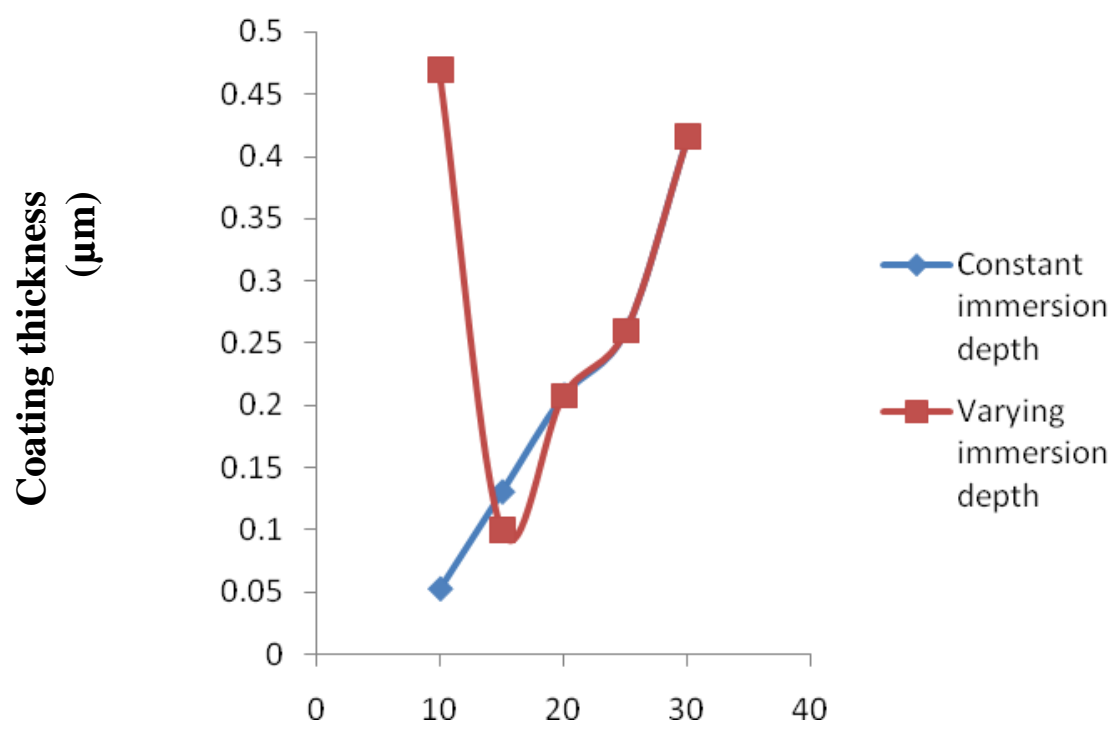

\section{Time (Mins)}

Fig. 6 Plot of Thickness $(\mu \mathrm{m})$ against Time (Mins) of zinc plated on low carbon steel at 30cm from the anode and at varying and constant immersion depth

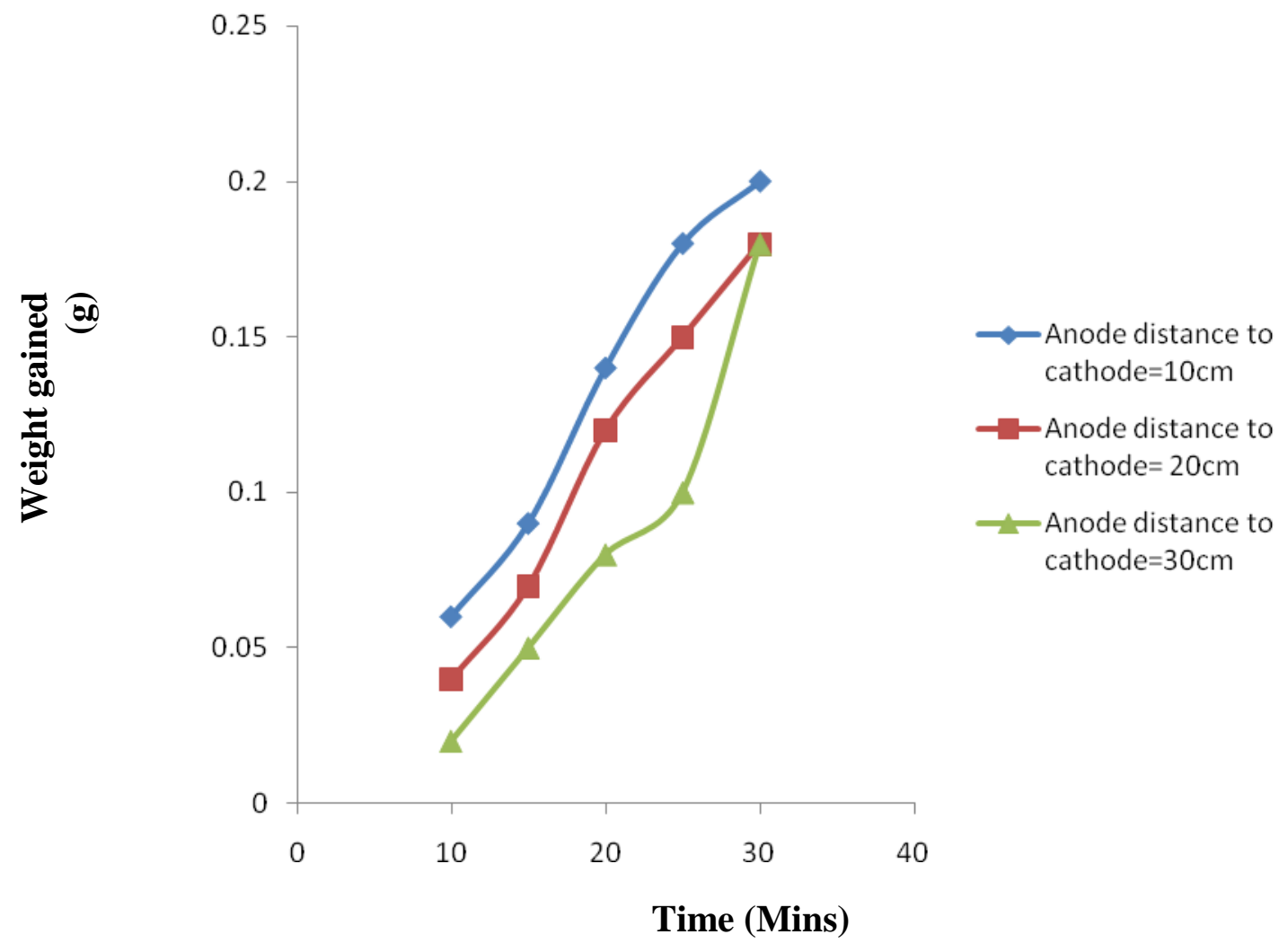

Fig 7 Plot of Weight gained (g) against Time (Mins) of zinc plated on low carbon steel at various constant distances $10 \mathrm{~cm}, 20 \mathrm{~cm}$ and $30 \mathrm{~cm}$ from the anode 


\section{DISCUSSION}

\subsection{Effect of Immersion Depth on Weight Gained and Coating Thickness}

Figures 1, 2 and 3 show that at given distances of $10 \mathrm{~cm}, 20 \mathrm{~cm}$ and $30 \mathrm{~cm}$ from anode weight gained increases as the plating time increases for the constant depth of immersion . However the weight gained per unit time by varying immersion depth is irregular. There is no linear relationship between electrodeposition and varying immersion depth. The same phenomenon is reflected for the thickness of coat film as revealed in Figures 4-6. So, the immersion depth must be controlled to avoid operating at point zero pumping action ${ }^{4}$.

However, Figure 5 projects a coincidence at 20mins plating time when the immersion depth was kept constant at $45 \mathrm{~cm}$ and when it was varied between $35 \mathrm{~cm}$ and $55 \mathrm{~cm}$. This phenomenon could probably explain the good electroplating effects experienced by the coated steel under the stated conditions.

\subsection{Effect of Distance from the Anode on Weight Gained}

Figure 7 relates the weight deposited against time at different distances from the anode. This indicates that as the distance from the anode increases the weight gained decreases.

\section{CONCLUSION}

This present study has demonstrated that electrodeposition increases at constant immersion depth at a given particular distance from anode while there is no linear relationship between electrodeposition and varying immersion depth.

However, this study showed that sample plated for 20 minutes; $20 \mathrm{~cm}$ from the anode, $45 \mathrm{~cm}$ depth of immersion at $0.8 \mathrm{~V}$ exhibited the best plating properties with homogeneity of diffuse plating efficiency.

\section{REFERENCES}

[1] Allen, S.H; Holowenko, A.R and Laughlin, H.G; 1982. Theory and Problems of Machine Design, McGraw Hill book company Inc. New York.

[2] Smith, W.F; 1990 Principle of materials science and Engineering, McGraw Hill international, New York.

[3] Sedlacek, V; 1993. Metallic Surface, Films and Coatings, McGraw Hill, London.

[4] Durney, L. J; 1984 Electroplating Engineering Handbook $4^{\text {th }}$ edition part 1, page 581. 